\title{
Capital Structure and Investment Growth Opportunity of Listed Pharmaceutical Firms in Nigeria
}

\author{
Shehu Usman Hassan ${ }^{1} \&$ Joseph Aitimon ${ }^{1}$ \\ ${ }^{1}$ Department of Accounting, Kaduna State University (KASU), Nigeria \\ Correspondence: Shehu Usman Hassan PhD, Department of Accounting, Kaduna State University (KASU), \\ Nigeria. Tel: 234-80-6776-6435, 234-80-5777-7085.
}

Received: February 25, 2017

Accepted: March 13, 2017

Online Published: April 6, 2017

doi:10.20849/abr.v2i1.138

URL: https://doi.org/10.20849/abr.v2i1.138

\begin{abstract}
This study assesses the impact of capital structure on investment opportunity growth, using listed pharmaceutical firms in Nigeria. The main objective of the study is to ascertain the level to which capital structures influences the investment opportunity growth of listed pharmaceutical firms in Nigeria. The methodology employed is the use of secondary data and the ex-post facto research design. The population of the study is all 7 pharmaceutical firms listed on the Nigerian Stock Exchange as at $31^{\text {st }}$ December, 2013. The study used regression as a tool of analysis. Findings show that Short term debt, total debt and performance were found to have significant, negative and strong effect on investment growth opportunity of Listed Pharmaceutical firms in Nigeria, while long term debt have no effect on investment growth opportunity of Listed Pharmaceutical firms in Nigeria, within the sturdy period. The study recommends that pharmaceutical firms should maintain a minimal level of short term debt because tying down too much of it current assets will reduce investment opportunity, also the management of listed Pharmaceutical firm should increase the level at which the organization uses long term debt to finance its business activities, as this may go a long way in increasing the investment opportunity potentials of the organizations, we also recommend that mmanagement should reduce the combination of its short term debt and long term debt and channel such to a highly profitable investment so that so that it will encourage them to invest more in other business opportunity that will bring more fortune to the business and shareholders at largemore room.
\end{abstract}

Keywords: total debt, short term debt, investment opportunity growth, pharmaceutical firms

\section{Introduction}

Capital structure explains how a company has financed its overall operations and growth by using diverse sources of funds. The management manipulates its capital structure in such a way as to reduce cost of funds and maximize the firm's value. Capital structure in a business entity includes cashes supplied through debt and equity. The origin and composition of the two types of capitals will supply financial consistency and the capability to pay the long-term liability of the company. Companies which finance through the common stocks are more attractive for investors and creditors because they do not have any claims prior to the common stocks. However, long-term liability and the outstanding stock can create leverage for the structure of a company and improve the return of owner equity. The novel theories of financial structure were posed in late 1950s and precisely after the publication of the famous paper written by Modigliani \& Miller (1958) and the presentation of irrelevance proposition. They presupposed in their theory that every company has a certain set of expected cash flows. When a company identifies a certain ratio of its liabilities and equities to finance its assets, it is trying to make decisions about how to divide cash flows mentioned among different investors. Also it is supposed that since the accessibility amounts of investors and companies to financial markets are the same, investors can supply all financial needs of the company (amount isn't important) and liquidate all unwanted liabilities for which the company has responsibility. Regarding the presuppositions above, Modigliani \& Miller (1958) concluded that the liabilities and capital structure of a company do not affect its market value (Alinezhad \& Taghizadeh, 2012).

Capital structure theories believe that the managers of firms with appropriate investment opportunities should choose a lower leverage because if they increase their external liabilities, they cannot use their investment opportunities' advantages. Thus, a negative relationship is created between the future growth and leverage 
because managers in firms with high growth opportunities will choose a lower leverage. Such results can be seen in regressions which control growth opportunities (Noraversh \& Yazdani, 2010).

The major objective of the study is to ascertain the level to which capital structure influences the investment growth of listed pharmaceutical firms in Nigerian. The specific objectives of the study are:

i) To examine the impact of Short term debt on Investment growth opportunity of listed Pharmaceutical firms in Nigeria.

ii) To determine the influence of Long term debt on Investment growth opportunity of listed Pharmaceutical firms in Nigeria;

iii) To investigate the effect of Total debt on Investment growth opportunity of listed Pharmaceutical firms in Nigeria.

The following null hypotheses were formulated in concordance with the above set out specific objectives of the study to test the influence of capital structures on investment opportunity growth of listed pharmaceutical firms in Nigerian.

$\mathrm{H}_{\mathrm{O} 1}$ Short term has no significant impact on Investment growth opportunity of listed Pharmaceutical firms in Nigeria.

$\mathrm{H}_{\mathrm{O} 2}$ Long term has no significant influence on Investment growth opportunity of listed Pharmaceutical firms in Nigeria.

$\mathrm{H}_{\mathrm{O} 3}$ Total debt has no significant effect on Investment growth opportunity of listed Pharmaceutical firms in Nigeria.

This research work will provide information to policy makers such as Nigerian Stock Exchange (NSE), Securities and Exchange Commission (SEC) and other stakeholders in Pharmaceutical regulation to strive hard in improving transparency, growth and a better mix of capital structure for listed Pharmaceutical companies in Nigeria. The work will also serve as a good reference material to those students who may wish to carry out further research on the subject matter and related discipline.

The rest of the paper is divided into four sections covering discussion on the literature review and theoretical framework, the research method and model specification, result and discussions and conclusion and recommendation.

\section{Review of Related Literature}

Individuals and organizations need financial data for decision making. Accounting information is one of the resources to do so. In theoretical fundamentals of financial reporting, the role of financial information and its usefulness has been stressed in individuals' decision makings. Financial Accounting Standards Board (FASB) and Accounting standards Board in Iran have emphasized on the theoretical framework of financial reporting to supply financial information in a way that the decision makings of the individuals is affected positively. One of the accounting items which should be supplied and presented in financial reporting (balance sheet) is liabilities. Usually liabilities are considered as a factor to predict and more importantly to guide for investment and making decisions. Thus, the investors are opt to realize the cash flow of an institution where they have invested to be able to judge about their stock value. Also they need cash flows and liquidity of the company to be able to estimate their stock values. Firms or individuals with liquidity in a period are able to repay the debts during the due time. On the other hand, the important thing in making decisions related to investment is the recognition of desirable and profitable growth opportunities.

Following Myers (1977), growth opportunities are considered in terms of the proportion of firm value accounted for by assets-in-place; the lower the fraction of firm value represented by assets-in place, the greater are the firm's growth opportunities or IOS. Mason and Merton (1985) Point out that firm with growth options are those that have relatively more capacity expansion projects, new product lines, acquisition of other firms and maintenance and replacement of existing assets. Three theories that might explain the association between IOS and corporate finance policy are the tax, signaling and contracting arguments (Gul, 1999). Regarding the fact that growth opportunities are considered as an invisible variable, it is difficult to measure and assess all opportunities (practical and potential) of a company simultaneously. But to remove this problem, the researchers have used different criteria during different periods. For example, (Smith \& Watts, 1992; Kole, 1991; Chung and Charoenwong, 1991; Collins and Kothari, 1989; Lewellen, Loderer, and Martin 1987; Gaver and Gaver, 1993; Bikki Jaggi \& Ferdinand 1999; Kallapour \& Trombley, 1999) have used three ratios to measure this variable as: market value of asset divided by book value, market value of stock divided by book value, and earnings per 
share to each share's price. Therefore, this study measures the growth opportunity as ratio of market value of equity to book value of equity because there are more opportunities in the capital market than other areas.

Smith and Watts (1992) and Kole (1991) measured growth opportunities as the ratio of the book value of assets to total firm value (A/V). Smith and Watts argued that the higher the $\mathrm{A} / \mathrm{V}$ ratio, the higher the ratio of assets in place to firm value and the lower the ratio of investment opportunities to firm value though this is restricted to internal investment as it deals with assets instead of equity. They pointed out, however, that because assets are measured at historical cost less depreciation, the $\mathrm{A} / \mathrm{V}$ ratio is likely to involve significant measurement error for firms with long-lived assets. Also, because firm value is measured as the market value of equity plus the book value of debt, the ratio involves measurement error for highly levered firms. Despite these arguments, it is always not the case, especially where firms are less levered.

A related measure of investment opportunities is the ratio of the market value of equity to the book value of equity, used by Chung and Charoenwong (1991), Collins and Kothari (1989), and Lewellen, Loderer, and Martin (1987). Collins and Kothari argued that the difference between the market value and the book value of equity roughly represents the value of investment opportunities facing the firm. The market-to-book equity ratio depends on the extent to which the firm's return on its existing assets and expected future investments exceeds its required rate of return on equity. Similarly, Lewellen, Loderer, and Martin (1987) contend that the volume of growth opportunities determines the future earnings rate on equity that the firm is expected to produce and the rate at which both earnings and cash flows are expected to grow over time. These are key determinants of the value per dollar of existing invested equity capital, that is, the market-to-book equity ratio (Smith and Warner, 1992). Another measure of the investment opportunity set, which is similar in spirit to the market-to-book ratios, is the earnings/price (EP) ratio used by Chung and Charoenwong (1991) Kester (1984), and Smith and Watts (1992). Chung and Charoenwong model equity value as the sum of the capitalized value of earnings generated from assets already in place, plus the net present value of the firm's future investment options. They show that the larger the EP ratio, the larger the proportion of equity value attributable to earnings generated from assets in place, relative to growth opportunities. Limiting assumptions of this analysis, however, are that current earnings are an adequate proxy for cash flows received from assets in place, and that these cash flows are received in perpetuity. In addition, the characterization is only meaningful for firms with nonnegative earnings (Smith and Warner, 1992).

The novel theory of capital structure was first presented by Modigliani \& Miller (1958). A lot of researchers carried out researches about capital structure in the following years. During the past decades, some patterns were presented to describe the fluctuations of debt ratio in different companies.

The static trade-off theory and the pecking order theory were posed in late 1970s (Harris \& Raviv). The first version of static trade-off theory was posed by Bradely \& et al (1984). But the taxation structure presupposed in the pattern mentioned does not accord with the present realities. According to static trade-off theory, firms are looking for an optimal capital structure (debt ratio) which maximizes the firm's value. In this theory, firms want to create a balance between the advantages and costs of debt issuances. The advantages of issuing debt can be tax shield and the reduction of the controversies among the benefits of stockholders and managers and the costs of debt issuance can contain the potential costs of bankruptcy and the controversies of the benefits of stockholders and creditors. In an optimal capital structure (debt ratio) the benefits of the last return of the debt only covers the costs resulted from it (Fama \& French, 2004).

According to pecking order theory which is resulted through the studies carried out by Myers \& Majluf (1984), there is no any optimal debt ratio and firms will try to supply financially without paying attention to optimal capital structure and only will consider the predetermined pecking order. In this theory, firms can finance through internal and external cash resources. It should be noted here that the internal cashes are in priority and external cashes will be used only when the internal ones are not enough. In this case debt issuance will be preferred to stock issuance. In other words, in pecking order theory, when the internal cash flows of a company are not enough to invest and pay the cash profit, firms issue debts and stocks never are issued unless the company is forced to issue debts with high interest rates and the financial crisis' cost is high (Sunder \& Myers, 1999). Thus, we can describe pecking order theory of a company's finance as: the first choice of the managers in using internal cashes (accumulated profit), then low-risk debt bonds and finally stock issuance (Alinezhad \& Taghizadeh, 2012).

Wagenvoort (2016) opined that the growth opportunities that a company has can determine how capital is structured. Both the Trade-off theory and Pecking order theory have a view on how the correlation between growth opportunities and leverage takes shape. The Trade-off theory argues that high growth firms are subject to 
increasing bankruptcy costs implying a negative correlation (Baskin, 1989). On the other hand the Pecking order theory states a positive correlation as companies with abundant growth opportunities often find that internal finance is insufficient and thus external financing is needed (De Jong, 1999). Preferring debt over equity in the Pecking order hierarchy leverage will increase with growth opportunities implying a positive correlation.

Most findings by scholars outside of the Netherlands agree with the Trade-off theory.Titman and Wessels (1988), Barclay et al. (1995), Rajan and Zingales (1995), Barclay and Smith (1999) and Graham (2000) all find a negative correlation. However within the Netherlands the variable growth opportunities is found to be positively correlated with leverage (Degryse et al., 2012; De Jong et al., 2008; De Bie andDe Haan, 2007; Chen et al., 1999).

\section{Research Methodology and Model Specification}

In choosing a particular design for a research work, it is usually based on the nature and the problem of the research and how best the research objectives can be achieved. The study adopts Ex-post facto design. The design is considered appropriate, in that, it is better in determining the relationship and degree of capital structure influence on investment growth opportunity in our study which may permit prediction. Ex-post facto design according to Denga and Ali (1983) is a design which helps to investigate possible cause and effect relationship by first identifying some existing consequence and searching back by analyzing data to establish possible causal factors. The data for this study were obtained mainly from secondary sources which were extracted from the annual report and account of listed conglomerate firms in Nigeria. The population of the study is all 7 pharmaceutical firms listed on the Nigerian Stock Exchange as at $31^{\text {st }}$ December, 2013. The justification for choosing Pharmaceutical firms to the best of our knowledge is premised on the fact that, it is still an area with paucity of studies. The study used the entire population as sample adopting census sampling technique. This research work is descriptive and highly empirical as it embraces the use of regression analysis where ordinary Least Square Technique is employed. Multiple regressions were used for the analysis and STATA 9-1 was used to run the regression.

The equation below represents the model of the study using balanced panel data of ordinary least square. This equation is represented as follows:

$$
\mathrm{IGO}_{\mathrm{it}}=\beta_{0 \mathrm{it}}+\beta_{1} \text { SDit }+\beta_{2} \text { LDit }+\beta_{3} \text { TDit }+\beta_{4} \text { PERFit }+\mu_{\mathrm{it}}
$$

Where;

$\begin{array}{ll}\mathrm{IGO} & =\text { Investment growth opportunity } \\ \mathrm{SD} & =\text { Short term debt } \\ \mathrm{LD} & =\text { Long term debt } \\ \mathrm{TD} & =\text { Total debt } \\ \mathrm{PERF} & =\text { Performance } \\ \beta 0 & =\text { the intercept/constant; } \\ \beta 1-\beta 4 & =\text { are the parameters; } \\ \mu & =\text { the residual/error term }\end{array}$

Table 1. Measurement of variables

\begin{tabular}{|c|c|c|}
\hline Nature of Variable & Proxy (ies) & Measurement \\
\hline $\begin{array}{l}\text { Dependent } \\
\text { Variable }\end{array}$ & $\begin{array}{l}\text { Investment growth } \\
\text { opportunity }\end{array}$ & $\begin{array}{l}\text { Ratio of market value of equity to book value of } \\
\text { equity }\end{array}$ \\
\hline Independent Variable & Short term debt & Ratio of short term debt to total assets \\
\hline " & Long term debt & Ratio of long term debt to total assets \\
\hline " & Total debt & $\begin{array}{l}\text { Ratio of total debt (short term plus long term } \\
\text { debt) to total assets }\end{array}$ \\
\hline Control variable & Return on Asset & Ratio of Profit after tax to total assets \\
\hline
\end{tabular}

Source: Author, 2016 


\section{Results and Discussion}

This segment deals with the preliminary analysis of the sample using descriptive statistics. This is followed by the presentation of result, analysis and interpretation of the data collected for the purpose of testing the model used in this study. Also, findings are discussed and policy implications from the finding are also drawn. The chapter ends with a discussion on the various robustness test conducted for the dependent and independent variable of the study.

\subsection{Descriptive Statistics}

The descriptive statistics for each of the variables were designed to show the Minimum, Maximum, Mean and Standard deviation, and skewness values. Descriptive statistics helps readers to understand the measures of central tendency, measures of variances associated with the variables of the study and the normality of the data used in the study.

Table 2. Descriptive statistics

\begin{tabular}{lllllll}
\hline Variables & N & Min & Max & Mean & Std. Dev. & Skewness \\
\hline Igo & 49 & -55.83 & 58.17 & 4.278 & 14.013 & -0.126 \\
\hline Sd & 49 & 0.13 & 0.94 & 0.526 & 0.198 & 0.207 \\
\hline Ld & 49 & 0.12 & 0.97 & 0.442 & 0.207 & 0.611 \\
\hline Td & 49 & 0.45 & 0.99 & 0.781 & 0.156 & -0.570 \\
\hline Perf & 49 & -2.76 & 5.92 & 0.138 & 1.083 & 2.588 \\
\hline
\end{tabular}

Source: Extract from STATA 9.1 Output

As presented in Table 2 the mean value of investment growth opportunity, short term debt, long term debt, total debt and performance are $4.278,0.526,0.442,0.781$, and 0.138 respectively. From the mean values as displayed above, short term debt and total debt have the highest mean values followed by the long term debt, this implies that the percentage of short term debt is high than the long term debt which means that the pharmaceutical firms use more of short term than long term debt probably because of the stringent conditions attach to long term debt. Looking at the percentage of total debt, it implies that $22 \%$ of the finances of the pharmaceutical companies if from equity shares while the remaining $78 \%$ is financed through short and long term debt. For performance used as control variable, the mean value is below $50 \%$ indicating a low performance level within the firms. The minimum Value for investment growth opportunity was 55.83 and a maximum value of 58.17 , short term debt minimum value stood at 0.13 and the maximum value is 0.94 , while the minimum value for long term debt is 0.12 and the maximum value is 0.97 . 0.45 were recorded for total debt as the minimum value while 0.99 was its maximum value. Performance minimum value stood at -2.76 and maximum value of 5.92. A study is considered valid when it is based on valid data, and this data is considered valid if obtained from the data quality. Using the descriptive statistics to test or determine whether there is data outlier in the study. The results of the skweness shows that all values were close to zero except for performance, thus, this clearly shows that the data is normally distributed, therefore we can consider the data to be tolerably mild.

\subsection{Correlation Matrix}

The correlation matrix is used to determine the association between the explained and the explanatory variables of the study. The table below therefore represents the correlation matrix for the sample observations. The full details are attached as appendix

Table 3. Correlation matrix

\begin{tabular}{llllll}
\hline Variable & IGO & SD & LD & TD & PERF \\
\hline IGO & 1 & & & & \\
\hline SD & $-0.2825^{* *}$ & 1 & & & \\
\hline LD & $-0.3147^{* *}$ & 0.1662 & 1 & & \\
\hline TD & $-0.3182^{* *}$ & 0.0127 & $0.3188^{* *}$ & 1 & \\
\hline PERF & $-0.7556^{*}$ & 0.1596 & $0.3819^{*}$ & 0.1951 & 1 \\
\hline
\end{tabular}

Source: Extract from STATA Output 
Table 3 indicates that there is a negative correlation between all the independent variables and the dependent variable. Short term debt is negatively and significantly related to investment growth opportunity to the level of about $28 \%$, long term debt correlate perfectly with investment growth opportunity to the tune of about $31 \%$, while total debt relates significantly with investment growth opportunity to about $32 \%$, and for performance relationship with investment growth opportunity is perfect and about $76 \%$. The correlation amongst the explanatory variables of the study is expected not to be too strong, and even if the correlation is strong, it should not be significant; therefore all the explanatory variables of the study are not too strongly related except for few of them that are significantly related contrary to what is expected. The tolerance values and the variance inflation factor (VIF) are two good measures generally concurred by various research scholars as being good measures for determining multicollinearity between the explanatory variables of a study. If the variance inflation factors of all the explanatory variables are less than ten (10), multicollinearity does not exist and the model is said to fit otherwise multicolinearity is assumed to exist. Another measure for determining the presence or absence of multicollinearity is the tolerance values. A tolerance value of 1 or above signifies the presence of multicollinearity, while tolerance values of less than 1.00 in all the observed variables signifies the absence of multicollinearity (Cassey et.al., 1999; Neter et.al., 1996).

The variance inflation factors of all the independent variables of the study are consistently less than 10 which is the benchmark for determining multicollinearity $(1.04<10,1.28<10,1.12<10$, and $1.19<10)$. In addition, the tolerance values are less than 1.00 which is another yardstick for determining multicollinearity $(.958918<1.00, .779710<1.00, .889594<1.00$ and $.838014<1.00)$. This shows the appropriateness of fitting the model of this study with four independent variables of the study. It also shows the complete absence of multicollinearity between the independent variables of the study. Thus, the results of this study can be applied with the guarantee that it evaluates what it purports to measure, that is, the relationship between short term debt and investment growth opportunity, long term debt and investment growth opportunity, total debt and investment growth opportunity, and also Firm performance and investment growth opportunity.

\subsection{Summary of Regression Result}

This table shows the regression result of the endogenous variable (IGO) and the exogenous variables of the study (SD, LD, TD, and PERF). The presentation is followed by the analysis of the relationship and contribution of all the independent variables to the dependent variable of the study and also the cumulative analysis.

Table 4. Summary of regression result

\begin{tabular}{lllll}
\hline Variables & Co-efficient & t-statistics & p-value & Tolerance / VIF \\
\hline Constant & 24.20466 & 3.19 & .003 & \\
SD & -12.37049 & -1.87 & .068 & $.958918 / 1.04$ \\
LD & 3.109164 & 0.44 & .660 & $.779710 / 1.28$ \\
TD & -17.33026 & -1.98 & .054 & $.889594 / 1.12$ \\
PERF & -9.15512 & -7.07 & .000 & $.838014 / 1.19$ \\
$\mathrm{R}^{2}$ & & & & 0.6309 \\
Adjusted R & & & & 0.5973 \\
F-statistics & & & & 18.80 \\
F-sig & & & & 0.000 \\
\hline
\end{tabular}

Source: Extract from STATA Output

The value of the regression co-efficient for the intercept describe a particular investment growth opportunity denominator for Listed Pharmaceutical firms in Nigeria, while the remaining co-efficient describe the impact of each explanatory variable on investment growth opportunity of Listed Pharmaceutical firms in Nigeria.

An $\mathrm{R}^{2}$ overall of 0.6309 indicates that 63.0 percent of the variation in investment growth opportunity can be explained by variability in short term debt, long term debt, total debt, and Performance. This means that short term debt, long term debt, total debt, and Performance occupy 63.0 percent in the factors that account for the investment growth opportunity of Listed Pharmaceutical firms in Nigeria and other factors account for the remaining 37.0 percent. It can be deduced that capital structure to a great extend influences the investment growth opportunity of Listed Pharmaceutical firms in Nigeria. 
The F-statistics also known as Fishers exact test have a value of 18.80 which is significant at one percent indicates that the investment growth opportunity model is fit. Hence, the outcome of the study can be greatly relied upon. The value of $\mathrm{F}$ which is statistically significant at $\%$ level of significant, which means that there is a 99.0 percent probability that the association among the variables is not due to mere chance.

The regression result shows that Short term debt as displayed in table 2.3 have a t-value of -1.87 and a coefficient value of -12.37049 with a significant value of $10 \%$. This signifies that short term debt (SD) has negative, strong and significant impact on investment growth opportunity of listed Pharmaceutical firms in Nigeria. This implies that for every One Naira (N1) increase in short term debt of the listed Pharmaceutical firms in Nigeria, the investment growth opportunity will decrease by N12.37. This provides an evidence of rejecting null hypothesis one of the study which states that Short term debt has no significant impact on investment growth opportunity.

The Long term debt has a t-value of 0.44 and a coefficient value of 3.109164 which is insignificant at either 1\% or 5\% level of significance. This signifies that Long term debt (LD) is positively, weak and insignificantly influencing the investment growth opportunity of listed Pharmaceutical firms in Nigeria. It implies that for every One Naira (N1) increase in long term debt of listed Pharmaceutical firms in Nigeria, the investment growth opportunity may not have any significant changes.

In view of the result with respect to long term debt showing that the variable is statistically insignificant in influencing investment growth opportunity, this therefore provides an evidence of failing to reject the null hypothesis two of the study. Thus, for hypothesis 2, H02 is failed to be rejected.

The Total debt has a t-value of -1.98 and a coefficient value of -17.33026 with a significant value of $5 \%$. This signifies that total debt (td) is strongly, negatively and significantly affecting the investment growth opportunity of listed Pharmaceutical firms in Nigeria. It implies that for every One Naira (N1) increase in total debt of listed Pharmaceutical firms, the investment growth opportunity will decrease by N17.33. This provides an evidence of failing to reject null hypothesis three of the study which states that Total debt has no significant contribution on investment growth opportunity.

The Profitability has a t-value of -7.07 and a coefficient value of -9.15512 with a significant value of $1 \%$. This signifies that Performance (Perf) is strongly, negatively and significantly impacting on the investment growth opportunity of listed Pharmaceutical firms in Nigeria. It implies that for every One Naira (N1) increase in performance of listed Pharmaceutical firms, the investment growth opportunity will decrease by N9.16.

\section{Conclusion and Recommendations}

Short term debt was found to have significant, negative and strong effect on investment growth opportunity of Listed Pharmaceutical firms in Nigeria, Therefore is concluded that any firm with a short term debt is likely to have decrease in investment growth opportunity.

Long term debt has no significant influence on investment growth opportunity of listed Pharmaceutical firms, therefore, it is concluded that any firm that is highly levered is likely to have no significance changes in their investment growth opportunity.

Total debt has significant negative impact on investment growth opportunity of Listed Pharmaceutical firms in Nigeria, therefore, it is concluded that any firm have high total debt is likely to have decrease in investment growth opportunity.

The findings of the study indicate that Performance has a strong, negative and significant, influence on investment growth opportunity of listed Pharmaceutical firms in Nigeria. The outcome is far from our expectation because any firm making a high profit is expected to increase their investment growth opportunity.

The recommendations of this study are made based on variety of people/organizations that are involved directly or indirectly with capital structure and investment growth opportunity processes in Nigeria.

The responsibility of increasing and maximizing the value of shareholders wealth in any organization especially listed companies in the Nigerian stock exchange is vested in the management team of those organizations which are in turn closely monitored by the Nigerian Securities and Exchange Commission (SEC). Therefore, SEC should ensure as much as possible that:

i. The management of pharmaceutical firms should maintain a minimal level of short term debt, i.e. debt that may be able to meet only its immediate current liability, as tying down too much amount of current asset will reduce investment opportunity which will have effect on the performance of the firms. 
ii. The management of listed Pharmaceutical firms should increase the level at which the organization uses long term debt to finance its business activities, as this may go a long way in increasing the investment opportunity potentials of the organizations

iii. The Management should reduce the combination of its short term debt and long term debt and channel such to a highly profitable investment so that it will encourage them to invest more in other business opportunity that will bring more fortune to the business and shareholders at large.

\section{References}

Aghaee, M. A., \& Shakeri, A. (2010). Using ratios of liquidity, cash flow and accrual accounting in predicting future operating cash flow of companies listed in Tehran Stock Exchange. Journal of Financial Accounting, Second Year, 5, 1-16.

Ahn, S., Denis, D., \& Denis, K. (2006). Leverage and Investment in Diversified Firms. Finance Economic Journals, 79, 317-337. https://doi.org/10.1016/j.jfineco.2005.03.002

Alinezhad, S. M., \& Taghizadeh, Kh. V. (2012). An overview of the theory of capital structure. The first National Conference on Noor Azad University.

Bikki, J., \& Ferdinand, A. G. (1999). An Analysis of Joint Effects of Investment Opportunity Set, Free Cash Flows and Size on Corporate Debt Policy. Review of Quantitative Finance and Accounting, $12,371$. https://doi.org/10.1023/A:1008354509316

Bradley, M., Jarrell, G. A., \& Kim, E. H. (1984). On the Existence of an Optimal Capital Structure: Theory and Evidence. Journal of Finance, 39(3). https://doi.org/10.1111/j.1540-6261.1984.tb03680.x

Chung, K., \& Charoenwong, C. (1991). Investment options, assets in place, and the risk of stocks. Financial Management, 20, 21-33. https://doi.org/10.2307/3665748

Collins, D. W., \& Kothari, S. P. (1989). An analysis of intertemporal and cross-sectional determinants of earnings response coefficients. Journal of Accounting and Economics, 11, 143-181. https://doi.org/10.1016/0165-4101(89)90004-9

Fama, E. F., \& French, K. R. (2004). The Capital Asset Pricing Model: Theory and Evidence. Journal of Economic Perspectives, 18, 25-40. https://doi.org/10.1257/0895330042162430

Ferdinand, A. G. (1999). Growth opportunities, capital structure and dividend policies in Japan. Journal of Corporate Finance, 5, 141-168. https://doi.org/10.1016/S0929-1199(99)00003-6

Gaver, J. J., \& Gaver, K. M. (1993). Additional evidence on the association between the investment opportunity set and corporate financing, dividend and compensation policies. Journal of Accounting and Economics, 16, 125-160. https://doi.org/10.1016/0165-4101(93)90007-3

Goyal, V., Lehn, K., \& Racic, S. (1998). Growth opportunities and corporate financial policies: The case of the US defense industry, 1980-1995. Unpublished paper.

Jensen, M. C. (1986, June). Agency cost of free cash flow, corporate finance, and takeovers. American Economic Review, 323-339.

Joseph, M. K., \& Kester, W. C. (1990). Japanese takeovers: The global contest for corporate control. Harvard Business School Press, Cambridge, MA.

Kallapur, S., \& Trombley, M. A. (1999). The Association between Investment Opportunity Set Proxies and Realized Growth. Journal of Business Finance \& Accounting, 26(3\&4), 505-519. https://doi.org/10.1111/1468-5957.00265

Lewellen, W., Loderer, C., \& Martin, K. (1987). Executive compensation contracts and executive incentive problems: An empirical analysis. Journal of Accounting and Economics, 9, 287-310. https://doi.org/10.1016/0165-4101(87)90009-7

Marion, R. H. (2004). An Analysis of the Association between Firms' Investment Opportunities, Board Composition, and Firm Performance. The University of Queensland-Accounting and Accountability.

Mason, S. P., \& Merton, R. C. (1985). The role of contingent claims analysis in corporate finance. In Altman, E.I. (Ed.), Recent Advances in Corporate Finance (pp. 7-54). Irwin, Homewood, IL.

Modigiliani, F., \& Miller, M. H. (1958). The cost of capital, corporation finance, and the theory of Investment. American Economic Review, 53, 433-443. 
Myers, S. C., \& Majluf, N. S. (1984). Corporate Financing and Investment Decisions When Firms Have Information that Investors Do Not Have. Journal of Financial Economics, 13(2). https://doi.org/10.1016/0304-405X(84)90023-0

Nasirzadeh, F., \& Mostaghimian, A. R. (2011). Investigation factors affecting on capital structure according to the theory of pecking order theory. Accounting ninth national congress of Iran, Zahedan, Sistan and Baluchestan University, pp. 109-121.

Noravesh, I., \& Yazdani, S. (2010). The effect of financial leverage on investment in companies listed in Tehran Stock Exchange. Journal of Financial Accounting, Second Year, (II), 35-48.

Rajan, R. G., \& Zingales, L. (1995). What Do We Know About Capital Structure? Some Evidence From $\begin{array}{llll}\text { International Data. Journal of } & \text { Finance, }\end{array}$ https://doi.org/10.1111/j.1540-6261.1995.tb05184.x

Rezvani, K., \& Haghighat, H. (2005). Studied the relationship between free cash flow and debt levels, considering the the investment opportunity and size in companies listed in Tehran Stock Exchange. Journal of Management, Second Year, (5). 50-57.

Sinai, H. A., Solgi, M., \& Mohammadi, K. (2011). The effect of growth opportunities on the relationship between capital structure, dividends, ownership structure and firm value. Journal of Financial Accounting, 3(4), 78-102.

Smith, C. W. Jr., \& Watts, R. L. (1992). The investment opportunity set and corporate financing, dividend and compensation policies. Journal of Financial Economics, 32, 263-292. https://doi.org/10.1016/0304-405X(92)90029-W

Sung, C. B. (2009). On the interactions of financing and investment decisions. Managerial Finance, 35(8), 691-699. https://doi.org/10.1108/03074350910967231

Titman, S., \& Wessels, R. (1988). The Determinant of Capital Structure Choice. The Journal of Finance, 43(1), 1-19. https://doi.org/10.1111/j.1540-6261.1988.tb02585.x

Vidhan, K., Goyal, K. L., \& Stanko, R. (2001). Grow Opportunity and Corporate Debt Policy: The Case of the U.S.D. Defence Industry. Hong Kong University of Science and Technology.

Wagenvoort, M. (2016). The firm specific determinants of capital structure and the influence of the financial crisis: Evidence from Dutch firms. 8th IBA Bachelor Thesis Conference, November 10th, 2016, Enschede, The Netherlands.

Appendix I

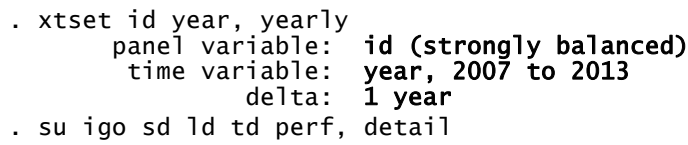

\begin{tabular}{|c|c|c|c|c|}
\hline $\begin{array}{r}1 \% \\
5 \% \\
10 \% \\
25 \%\end{array}$ & $\begin{array}{r}\text { Percentiles } \\
-55.83 \\
-10.12 \\
.56 \\
1.52\end{array}$ & $\begin{array}{r}\text { Sma11est } \\
-55.83 \\
-14.54 \\
-10.12 \\
-8.64\end{array}$ & $\begin{array}{l}\text { Obs } \\
\text { Sum of wgt. }\end{array}$ & $\begin{array}{l}49 \\
49\end{array}$ \\
\hline $50 \%$ & 2.34 & Largest & $\begin{array}{l}\text { Mean } \\
\text { std. Dev. }\end{array}$ & $\begin{array}{l}4.277959 \\
14.01305\end{array}$ \\
\hline $\begin{array}{l}75 \% \\
90 \% \\
95 \% \\
99 \%\end{array}$ & $\begin{array}{r}6.35 \\
12.96 \\
20.86 \\
58.17\end{array}$ & $\begin{array}{l}13.42 \\
20.86 \\
40.86 \\
58.17\end{array}$ & $\begin{array}{l}\text { Variance } \\
\text { Skewness } \\
\text { Kurtosis }\end{array}$ & $\begin{array}{r}196.3656 \\
-.1256362 \\
13.00358\end{array}$ \\
\hline
\end{tabular}




\begin{tabular}{|c|c|c|c|c|}
\hline $\begin{array}{r}1 \% \\
5 \% \\
10 \% \\
25 \%\end{array}$ & $\begin{array}{r}\text { Percentiles } \\
.13 \\
.25 \\
.25 \\
.39\end{array}$ & $\begin{array}{r}\text { Sma11est } \\
.13 \\
.23 \\
.25 \\
.25\end{array}$ & $\begin{array}{l}\text { Obs } \\
\text { Sum of wgt. }\end{array}$ & $\begin{array}{l}49 \\
49\end{array}$ \\
\hline $50 \%$ & .5 & I argest & $\begin{array}{l}\text { Mean } \\
\text { std. Dev }\end{array}$ & $\begin{array}{l}.5259184 \\
.1980206\end{array}$ \\
\hline $\begin{array}{l}75 \% \\
90 \% \\
95 \% \\
99 \%\end{array}$ & $\begin{array}{l}.71 \\
.83 \\
.84 \\
.94\end{array}$ & $\begin{array}{l}.83 \\
.84 \\
.84 \\
.94\end{array}$ & $\begin{array}{l}\text { Variance } \\
\text { Skewness } \\
\text { Kurtosis }\end{array}$ & $\begin{array}{l}.0392122 \\
.2067684 \\
2.140158\end{array}$ \\
\hline
\end{tabular}

\begin{tabular}{|c|c|c|c|c|}
\hline $\begin{array}{r}1 \% \\
5 \% \\
10 \% \\
25 \%\end{array}$ & $\begin{array}{r}\text { Percentiles } \\
.12 \\
.15 \\
.18 \\
.29\end{array}$ & $\begin{array}{r}\text { Sma17est } \\
.12 \\
.14 \\
.15 \\
.17\end{array}$ & $\begin{array}{l}\text { Obs } \\
\text { Sum of wgt. }\end{array}$ & $\begin{array}{l}49 \\
49\end{array}$ \\
\hline $50 \%$ & .42 & largest & Mean & $\begin{array}{r}.4418367 \\
.20714\end{array}$ \\
\hline $\begin{array}{l}75 \% \\
90 \% \\
95 \% \\
99 \%\end{array}$ & $\begin{array}{l}.54 \\
.69 \\
.85 \\
.97\end{array}$ & $\begin{array}{l}.85 \\
.85 \\
.92 \\
.97\end{array}$ & $\begin{array}{l}\text { Variance } \\
\text { Skewness } \\
\text { Kurtosis }\end{array}$ & $\begin{array}{r}.042907 \\
.6111465 \\
2.951581\end{array}$ \\
\hline
\end{tabular}

\begin{tabular}{|c|c|c|c|c|}
\hline $\begin{array}{r}1 \% \\
5 \% \\
10 \% \\
25 \%\end{array}$ & $\begin{array}{c}\text { Percentiles } \\
.45 \\
.49 \\
.53 \\
.67\end{array}$ & $\begin{array}{r}\text { Sma11est } \\
.45 \\
.45 \\
.49 \\
.53\end{array}$ & $\begin{array}{l}\text { Obs } \\
\text { Sum of wgt. }\end{array}$ & $\begin{array}{l}49 \\
49\end{array}$ \\
\hline $50 \%$ & .83 & Largest & $\begin{array}{l}\text { Mean } \\
\text { Std. Dev. }\end{array}$ & $\begin{array}{l}.7810204 \\
.1557408\end{array}$ \\
\hline $\begin{array}{l}75 \% \\
90 \% \\
95 \% \\
99 \%\end{array}$ & $\begin{array}{l}.88 \\
.97 \\
.98 \\
.99\end{array}$ & $\begin{array}{r}.98 \\
.98 \\
.98 \\
.99\end{array}$ & $\begin{array}{l}\text { Variance } \\
\text { Skewness } \\
\text { Kurtosis }\end{array}$ & $\begin{array}{r}.0242552 \\
-.5699117 \\
2.268543\end{array}$ \\
\hline
\end{tabular}

\begin{tabular}{|c|c|c|c|c|}
\hline $\begin{array}{r}1 \% \\
5 \% \\
10 \% \\
25 \%\end{array}$ & $\begin{array}{r}\text { Percentiles } \\
-2.76 \\
-1.25 \\
-.78 \\
-.13\end{array}$ & $\begin{array}{r}\text { Sma11est } \\
-2.76 \\
-2.03 \\
-1.25 \\
-.91\end{array}$ & $\begin{array}{l}\text { Obs } \\
\text { Sum of wgt. }\end{array}$ & $\begin{array}{l}49 \\
49\end{array}$ \\
\hline $50 \%$ & .15 & Largest & $\begin{array}{l}\text { Mean } \\
\text { Std. Dev. }\end{array}$ & $\begin{array}{r}.137551 \\
1.083145\end{array}$ \\
\hline $\begin{array}{l}75 \% \\
90 \% \\
95 \% \\
99 \%\end{array}$ & $\begin{array}{r}.33 \\
.78 \\
.86 \\
5.92\end{array}$ & $\begin{array}{r}.84 \\
.86 \\
1.35 \\
5.92\end{array}$ & $\begin{array}{l}\text { Variance } \\
\text { Skewness } \\
\text { Kurtosis }\end{array}$ & $\begin{array}{l}1.173202 \\
2.588234 \\
18.85047\end{array}$ \\
\hline
\end{tabular}

- pwcorr igo sd 1d td perf, star (0.05) sig

\begin{tabular}{|c|c|c|c|c|c|}
\hline & igo & sd & $1 d$ & td & perf \\
\hline igo & 1.0000 & & & & \\
\hline sd & $\begin{array}{c}-0.2825^{*} \\
0.0492\end{array}$ & 1.0000 & & & \\
\hline $1 d$ & $\begin{array}{c}-0.3147^{*} \\
0.0276\end{array}$ & $\begin{array}{l}0.1662 \\
0.2537\end{array}$ & 1.0000 & & \\
\hline $\mathrm{td}$ & $\begin{array}{c}-0.3182^{*} \\
0.0258\end{array}$ & $\begin{array}{l}0.0127 \\
0.9310\end{array}$ & $\begin{array}{l}0.3188^{*} \\
0.0256\end{array}$ & 1.0000 & \\
\hline perf & $\begin{array}{c}-0.7556^{*} \\
0.0000\end{array}$ & $\begin{array}{l}0.1596 \\
0.2734\end{array}$ & $\begin{array}{l}0.3819 * \\
0.0068\end{array}$ & $\begin{array}{l}0.1951 \\
0.1791\end{array}$ & 1.0000 \\
\hline
\end{tabular}


. reg igo sd $1 d$ td perf

\begin{tabular}{|c|c|c|c|c|c|c|c|}
\hline Source & SS & $d f$ & \multicolumn{2}{|c|}{ MS } & & \multirow{3}{*}{$\begin{array}{l}\text { Number of obs } \\
\text { F( 4, } 44) \\
\text { Prob }>\text { F } \\
\text { R-squared } \\
\text { Adj R-squared } \\
\text { Root MSE }\end{array}$} & \multirow{3}{*}{$\begin{array}{rr}= & 49 \\
= & 18.80 \\
= & 0.0000 \\
= & 0.6309 \\
= & 0.5973 \\
= & 8.892\end{array}$} \\
\hline $\begin{array}{r}\text { Mode1 } \\
\text { Residua1 }\end{array}$ & $\begin{array}{l}5946.59184 \\
3478.95475\end{array}$ & $\begin{array}{r}4 \\
44\end{array}$ & $\begin{array}{l}1486 \\
79.0\end{array}$ & $\begin{array}{l}64796 \\
71535\end{array}$ & & & \\
\hline Total & 9425.5466 & 48 & 196. & 65554 & & & \\
\hline igo & coef. & std. & Err. & $t$ & $P>|t|$ & [95\% Conf. & Interval] \\
\hline $\begin{array}{r}\text { sd } \\
1 d \\
t d \\
\text { perf } \\
\text { _cons }\end{array}$ & $\begin{array}{r}-12.37049 \\
3.109164 \\
-17.33026 \\
-9.15512 \\
24.20466\end{array}$ & $\begin{array}{l}6.618 \\
7.016 \\
8.737 \\
1.294 \\
7.579\end{array}$ & $\begin{array}{l}757 \\
929 \\
337 \\
391 \\
009\end{array}$ & $\begin{array}{r}-1.87 \\
0.44 \\
-1.98 \\
-7.07 \\
3.19\end{array}$ & $\begin{array}{l}0.068 \\
0.660 \\
0.054 \\
0.000 \\
0.003\end{array}$ & $\begin{array}{r}-25.70972 \\
-11.03253 \\
-34.9392 \\
-11.76379 \\
8.930175\end{array}$ & $\begin{array}{r}.9687381 \\
17.25086 \\
.2786882 \\
-6.546447 \\
39.47915\end{array}$ \\
\hline
\end{tabular}

. vif

\begin{tabular}{r|rr} 
Variable & VIF & $1 /$ VIF \\
\hline Id & 1.28 & 0.779710 \\
perf & 1.19 & 0.838014 \\
td & 1.12 & 0.889594 \\
sd & 1.04 & 0.958918 \\
\hline Mean VIF & 1.16 &
\end{tabular}

. hettest

Breusch-Pagan / Cook-Weisberg test for heteroskedasticity Ho: Constant variance

variables: fitted values of igo

$\begin{array}{llr}\operatorname{chi}(1) & 1.74 \\ \text { Prob }>\text { chi2 } & = & 0.1875\end{array}$

\section{Copyrights}

Copyright for this article is retained by the author(s), with first publication rights granted to the journal.

This is an open-access article distributed under the terms and conditions of the Creative Commons Attribution license (http://creativecommons.org/licenses/by/4.0/). 